\title{
Estrogen Induces CK2 $\alpha$ Activation via Generation of Reactive Oxygen Species
}

\author{
Soo-Yeon Jeong ${ }^{*}$ and Suhn-Young Im $^{\dagger ; * *}$ \\ Department of Biological Sciences, College of Natural Sciences, Chonnam National University, \\ Gwangju 61186, Korea
}

\begin{abstract}
The protein kinase CK2 $\alpha$ (formerly Casein Kinase II) is implicated in tumorigenesis and transformation. However, the mechanisms of CK2 $\alpha$ activation in breast cancer have yet to be elucidated. This study investigated the mechanisms of CK2 $\alpha$ activation in estrogen signaling. Estrogen increased reactive oxygen species (ROS) production, CK2 $\alpha$ activity, and protein expression in estrogen receptor positive (ER $\left.{ }^{+}\right)$MCF-7 human breast cancer cells, which were inhibited by the antioxidant $\mathrm{N}$-acetyl-L-cysteine. $\mathrm{H}_{2} \mathrm{O}_{2}$ enhanced CK2 $\alpha$ activity and protein expression. Human epidermal growth factor (EGF) increased ROS production, CK2 $\alpha$ activity and protein expression in EGF receptor 2 (HER2)-overexpressing MCF-7 (MCF-7 HER2) cells, but not in MCF-7 cells. Estrogen induced the phosphorylation of p38 mitogen-activated protein kinase (MAPK). The p38 inhibitor, SB202190, blocked estrogen-induced increases in ROS production, CK2 $\alpha$ activity and CK2 $\alpha$ protein expression. The data suggest that ROS/p38 MAPK is the key inducer of CK2 $\alpha$ activation in response to estrogen or EGF.
\end{abstract}

Key Words: Estrogen, CK2 $\alpha$, ROS, P38 MAPK

\section{INTRODUCTION}

Breast cancer is the most common cause of cancer death among women (Ferlay et al., 2010), and is characterized by molecular and cellular heterogeneity (Perou et al., 2000). The etiology of breast cancer is multifactorial, with major risk factors including age, early menarche, delayed menopause, use of contraceptives or oral medications, hormone therapy, family history, history of benign breast disease, and obesity; estrogen is a major risk factor for breast carcinogenesis and growth of breast cancer cells (Yager and Liehr, 1996; Clemons and Goss, 2001).

Reactive oxygen species (ROS) act as potent mutagens, increasing genomic instability and initiation as well as the progression of cancer (Carew and Huang, 2002). Oxidative stress is one of the mechanisms underlying the carcinogenic effect of estrogen in breast cancer. Genotoxic estrogen metabolites such as catechols and estrogen-semi-quinones generated during estrogen metabolism are known to produce ROS (Roy et al., 2007; Okoh et al., 2011). Mitochondria are the main source of estrogen-induced ROS in breast cancer cells (Felty et al., 2005; Parkash et al., 2006).

Protein kinase CK2 $\alpha$ (formerly Casein Kinase 2 or II) is a highly conserved and ubiquitous serine/threonine kinase, which is localized in the cell nucleus and cytoplasm. CK2 $\alpha$ is a tetrameric complex composed of catalytic ( $\alpha$ or $\left.\alpha^{\prime}\right)$ and regulatory ( $\beta$ ) subunits with a $\alpha_{2} \beta_{2}$, $\alpha \alpha^{\prime} \beta_{2}$, or $\alpha_{2}^{\prime} \beta_{2}$ structure

Received: October 22, 2018 / Revised: February 8, 2019 / Accepted: February 12, 2019

* Graduate student, ${ }^{* *}$ Professor.

${ }^{\dagger}$ Corresponding author: Suhn-Young Im. Department of Biological Sciences, College of Natural Sciences, Chonnam National University, Gwangju 61186, Korea.

Tel: +82-62-530-3414, Fax: +82-62-530-3409, e-mail: syim@chonnam.ac.kr

(C) The Korean Society for Biomedical Laboratory Sciences. All rights reserved.

(c) This is an Open Access article distributed under the terms of the Creative Commons Attribution Non-Commercial License (http://creativecommons.org/licenses/by-nc/3.0/) which permits unrestricted non-commercial use, distribution, and reproduction in any medium, provided the original work is properly cited. 
(Allende and Allende, 1995). CK2 $\alpha$ modulates 300 potential substrates in the cell, as well as a wide range of pathways related to cell growth, proliferation and apoptosis (Litchfield, 2003; Duncan and Litchfield, 2008). CK2 $\alpha$ is implicated in tumorigenesis and transformation. CK2 $\alpha$ inhibits the activity and stability of tumor suppressor proteins (p53 and phosphatase and tensin homolog deleted on chromosome 10 (PTEN)), promotes cell survival signaling via up-regulation of protooncogenic products (c-Myc, c-Myb, and c-Jun) and transcriptional activators ( $\alpha$-catenin and Max) (Singh and Ramji, 2008). Overexpression of CK $2 \alpha$ has been observed in many human cancers, including breast cancers (Filhol et al., 2015; Chua et al., 2017). However, the underlying mechanisms of CK2 $\alpha$ expression in breast cancers remain elusive.

The molecular mechanism underlying the activation of CK2 $\alpha$ is mediated via ROS (Kim et al., 2014). Therefore, it is of interest to investigate whether a similar mechanism occurs in estrogen signaling. In this study, we found that estrogen increased CK2 $\alpha$ activation and expression via ROS /p38 mitogen activated protein kinase (MAPK) in estrogen receptor-positive $\left(\mathrm{ER}^{+}\right)$cell lines.

\section{MATERIALS AND METHODS}

\section{Cell cultures}

MCF-7 and T47D, MBA-MB-231 human breast cancer cells (American Type Culture Collection, ATCC, Manassas, VA, USA Rockville, MD, USA) were cultured in Dulbecco's Modified Eagle's Medium (DMEM) or RPMI1640 medium (GIBCO Invitrogen, Carlsbad, CA, USA) supplemented with $10 \%$ (volume/volume) fetal bovine serum (GIBCO Invitrogen, Carlsbad, CA, USA) at $37^{\circ} \mathrm{C}$ in a humidified atmosphere of $5 \% \mathrm{CO}_{2}$ and $95 \%$ air. MCF-7 overexpressing HER2 $\left(\mathrm{MCF}-7\right.$ HER2 ${ }^{+}$) and vector control (MCF-7 vec) cells were kindly provided by professor Ko, and were described elsewhere (Seo et al., 2012).

\section{Antibodies and reagents}

The following antibodies were used for Western blot analysis. Anti-phospho-CK2 (Thr306, Ser362) (Sigma-Aldrich, St Louis, MO, USA), anti-CK2 $\alpha$, anti-phospho-p38 mitogen activated protein kinase (MAPK) (Thr180, Tyr182), anti-
phospho-JNK anti-phospho-ERK were purchased from Cell Signaling Technology (Beverly, MA, USA). Anti-GAPDH, anti-normal rabbit IgG were from Santa Cruz Biotechnology (Santa Cruz, CA, USA). The antioxidant, N-Acetyl-L-Cysteine (Sigma-Aldrich), p38 inhibitor (SB202190, 5 mg/kg), JNK inhibitor (SP600125, $12.5 \mathrm{mg} / \mathrm{kg}$ ) or ERK inhibitor (PD98059, $12.5 \mathrm{mg} / \mathrm{kg}$ ) were purchased from Calbiochem Merck (Darmstadt, Germany).

\section{Measurement of intracellular ROS}

The oxidation-sensitive fluorescent probes $\mathrm{CM}-\mathrm{H}_{2} \mathrm{DCF}$ DA were used to monitor the production of hydrogen peroxide. Cells in each well were treated with estrogen and/or reagents for $3 \mathrm{hr}$, after which they were incubated with $5 \mu \mathrm{M}$ CM-H ${ }_{2}$ DCF-DA (DCF) (Sigma-Aldrich) for the detection of cytosolic ROS for $30 \mathrm{~min}$ at $37^{\circ} \mathrm{C}$ in the dark. Fluorescence was read with excitation at $485 \mathrm{~nm}$ and emission at 530土 $30 \mathrm{~nm}$ with an automated microplate reader (Ininite ${ }^{\mathrm{TM}} \mathrm{M} 200$ (Tecan, AG, Switzerland).

\section{CK2 $\alpha$ activity assay}

Cells were homogenized in lysis buffer $(50 \mathrm{mM}$ Tris- $\mathrm{HCl}$, $\mathrm{pH} 7.5,150 \mathrm{mM} \mathrm{NaCl}, 1 \%$ Triton $\mathrm{X}-100,0.5 \%$ sodium deoxycholate, $0.1 \%$ SDS, 1 mM EGTA, 1 mM EDTA, 10 $\mathrm{mM}$ sodium fluoride, $1 \mathrm{mM}$ sodium orthovanadate, $1 \mathrm{mM}$ dithiothreitol and $1 \mathrm{mM}$ PMSF). The phosphotransferase activity of CK2 $\alpha$ was measured using a CK2 $\alpha$ assay kit (Millipore, Temecula, CA, USA) in accordance with the manufacturer's recommendations. Briefly, cell lysates, substrate peptide, protein kinase A inhibitor cocktail, and $\gamma$ $\left[{ }^{32} \mathrm{P}\right]$ ATP in the assay dilution buffer were incubated for 10 $\min$ at $30^{\circ} \mathrm{C}$. The phosphorylated substrate was then separated on P81 phosphocellulose paper and quantified with a scintillation counter.

\section{Western blot analysis}

Whole cell extracts were prepared using PhosphoSafe Extraction Reagent (Novagen Merck, Darmstadt, Germany) with phenylmethylsulfonyl fluoride protease inhibitor (SigmaAldrich, St Louis, MO, USA). Equal amounts of cell lysates were separated on $10 \%$ SDS-polyacrylamide gel under reducing conditions, and electrophoretically transferred onto 
Protran Nitrocellulose Transfer Membranes (Whatman, Dassel, Germany). The membranes were blocked by $30 \mathrm{~min}$ of incubation at room temperature (RT) in 5\% BSA in Trisbuffered saline (TBS)-0.1\% Tween 20, followed by $2 \mathrm{hr}$ incubation at $4{ }^{\circ} \mathrm{C}$ with primary antibodies in 5\% BSA in TBS$0.1 \%$ Tween 20 . The blots were washed for 30 min with three changes of TBS- $0.1 \%$ Tween 20 solution, followed by incubation for $1 \mathrm{hr}$ at RT with horseradish peroxidaseconjugated anti-rabbit IgG antibody (Santa Cruz Biotechnology, Santa Cruz, CA, USA). The blots were again washed three times for $30 \mathrm{~min}$ each, and finally developed in LumiGLO reagent (ECL, GE Health Care UK Limited Cell Sig- naling Technology, Beverly, MA, USA). GAPDH was used as a loading control. The density of each band was determined using the densitometry Fluor-STM Imager (Bio-Rad, Muncher, Germany).

\section{Statistical analysis}

Data are expressed as means \pm SE Statistical significance was determined via one-way analysis of variance (StatView; Abacus Concepts Inc., Berkeley, CA, USA). All experiments were conducted at least twice. Reproducible results were obtained and representative data are, therefore, provided in the figures.
A

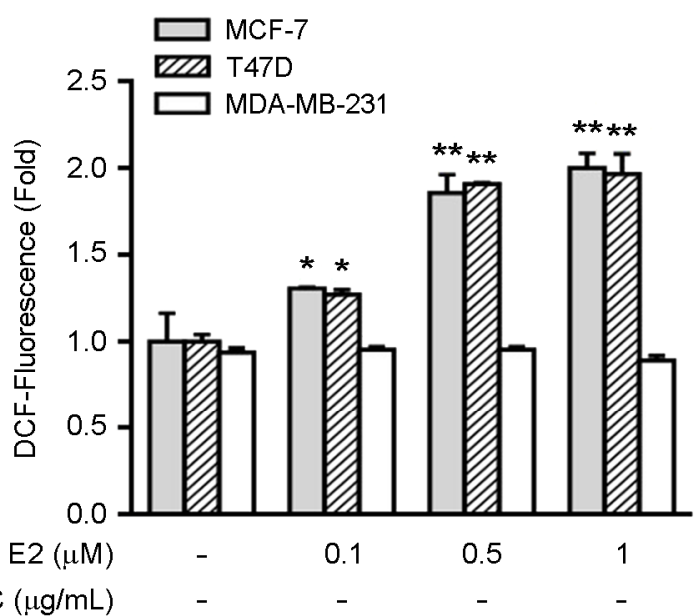

C
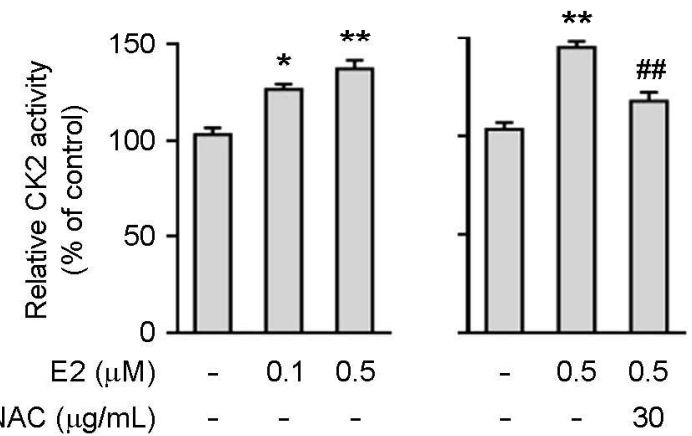

B

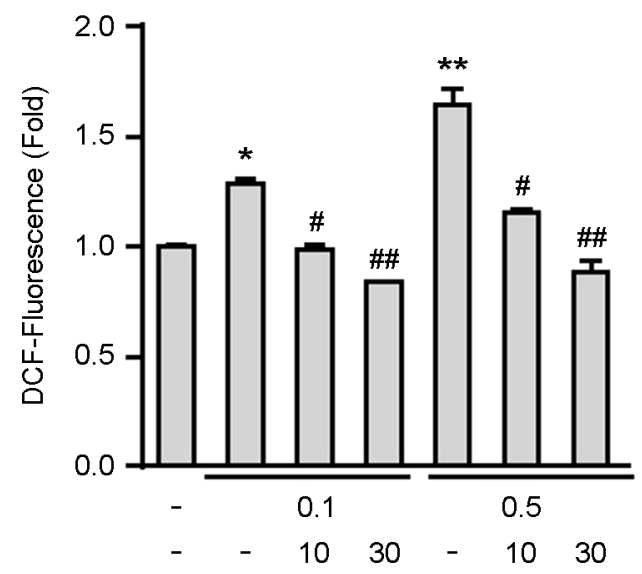

(D)

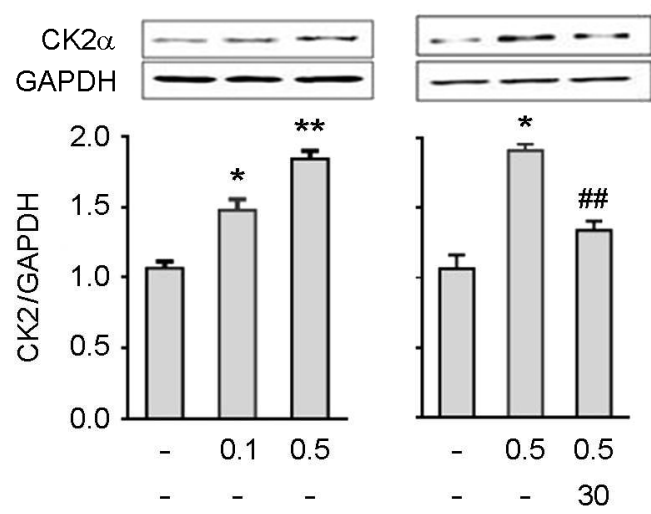

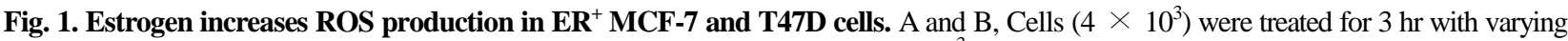
concentrations of estrogen for the measurement of ROS. B, MCF-7 cells $\left(4 \times 10^{3}\right)$ were treated for $3 \mathrm{hr}$ with varying concentrations of estrogen NAC $(10$ or $30 \mu \mathrm{g} / \mathrm{mL})$ was added 30 min before estrogen $(0.1$ or $0.5 \mu \mathrm{M})$ treatment $(\mathrm{B})$. C and $\mathrm{D}$, Cells $\left(1 \times 10^{6}\right)$ were treated with NAC and/or estrogen for the measurement of CK2 activity (C) and protein expression (D). Data represent the mean \pm SE of two to three independent experiments with three to five samples per experiment. ${ }^{*} P<0.01$ versus control group. ${ }^{* * *} P<0.001$ versus control group. ${ }^{\#} P<0.01$ versus estrogen-treated group. ${ }^{\#} P<0.001$ versus estrogen-treated group. 
(A)

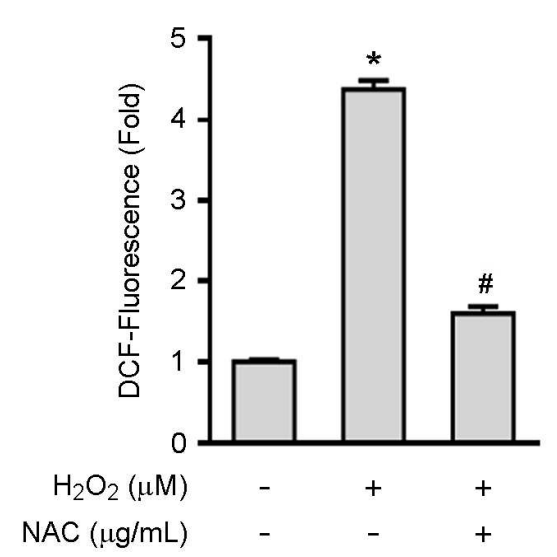

B

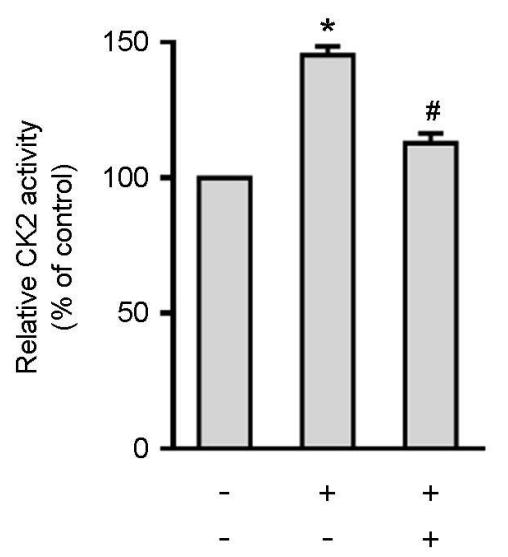

C
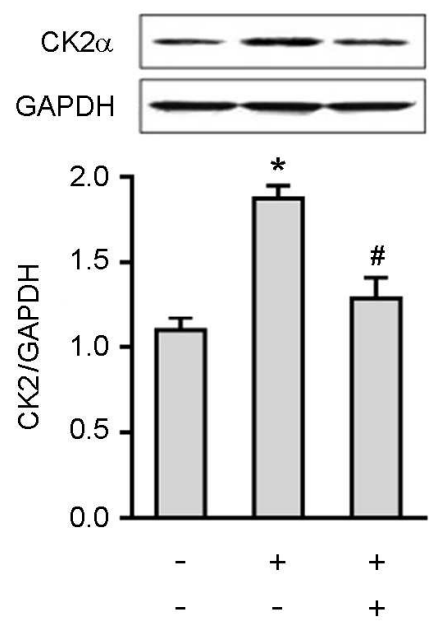

Fig. 2. $\mathrm{H}_{2} \mathrm{O}_{2}$ increases CK2 activity and protein expression in MCF-7 cells. A, Cells $\left(4 \times 10^{3} /\right.$ well for A; $2 \times 10^{6} /$ well for B and C) were pretreated with NAC $(30 \mu \mathrm{g} / \mathrm{mL})$ for $30 \mathrm{~min}$ followed by $\mathrm{H}_{2} \mathrm{O}_{2}(30 \mu \mathrm{M})$ for $3 \mathrm{hr}$ to quantify ROS levels (A), CK2 activity (B) and protein expression $(\mathrm{C})$. Data represent the mean $\pm \mathrm{SE}$ of two to three independent experiments with three to five samples per experiment. ${ }^{*} P$ $<0.001$ versus control group. ${ }^{\sharp} P<0.001$ versus $\mathrm{H}_{2} \mathrm{O}_{2}$-treated group.

\section{RESULTS}

\section{Estrogen increases ROS production and CK2 $\alpha$ expression}

We first assessed the effect of estrogen on ROS production and CK2 $\alpha$ expression using estrogen receptor (ER)-positive MCF-7 and T47D and ER-negative MDA-MB-231 breast cancer cells. ROS production was increased about 1.7-fold in $\mathrm{ER}^{+} \mathrm{MCF}-7$ and T47D cells upon estrogen stimulation, but such increase was not observed in ER-negative MDAMB-231 cells (Fig. 1A). The presence of NAC, a commonly used ROS scavenger, blocked the estrogen-induced ROS production (Fig. 1B). CK2 $\alpha$ activity was increased in a dosedependent manner in MCF-7 cells upon estrogen stimulation (Fig. 1C). We also investigated the effect of estrogen on CK2 $\alpha$ protein expression by Western blot analysis, which revealed that estrogen increased $\mathrm{CK} 2 \alpha$ protein expression in MCF-7 cells in dose-dependent manners (Fig. 1D). Both estrogen-induced $\mathrm{CK} 2 \alpha$ activity and protein expression were blocked by NAC (Fig. 1C and D). We analyzed the direct role of ROS in CK2 $\alpha$ activity and protein expression. The addition of $\mathrm{H}_{2} \mathrm{O}_{2}$ to MCF-7 cells resulted in increases in ROS production (Fig. 2A), CK2 $\alpha$ activity (Fig. 2B) and protein expression (Fig. 2C), which were blocked by NAC. These data indicate that estrogen upregulates $\mathrm{CK} 2 \alpha$ activity and protein expression via ROS production in $\mathrm{ER}^{+}$breast cancer cells.

Comparison of ROS production, p38 phosphorylation, and CK2 $\alpha$ activity and protein expression: MCF-7 versus MCF-7 HER2 cells

MCF-7 vec and MCF-7 HER2 ${ }^{+}$cells were stimulated either estrogen alone or estrogen combined with EGF. When the cells were exposed to estrogen alone, ROS production (Fig. 3A), p38 phosphorylation (Fig. 3B), CK2 $\alpha$ activity (Fig. 3C), and protein expression (Fig. 3D) were increased similarly in both cell lines. When the cells were stimulated with EGF alone, ROS production (Fig. 3A), p38 phosphorylation (Fig. 3B), CK2 $\alpha$ activity (Fig. 3C), and protein expression (Fig. 3D) were only increased in MCF-7 HER2 ${ }^{+}$ cells. When the cells were treated with estrogen + EGF, more higher increases in ROS production (Fig. 3A), p38 phosphorylation (Fig. 3B), CK2 $\alpha$ activity (Fig. 3C) and protein expression (Fig. 3D) were observed in MCF-7 HER2 ${ }^{+}$cells compared to MCF-7 vec cells. All the increases of ROS production and $\mathrm{CK} 2 \alpha$ activity, and protein expression induced by exposure to estrogen combined with EGF in MCF-7 HER $2^{+}$cells were blocked by pre-treatment with NAC (Fig. 3A-D). These data indicate that the presence of HER2 in breast cells contributes to higher levels of ROS production 
A

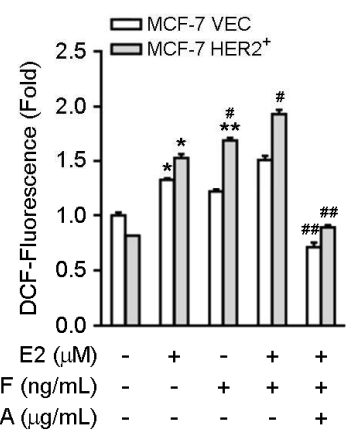

B
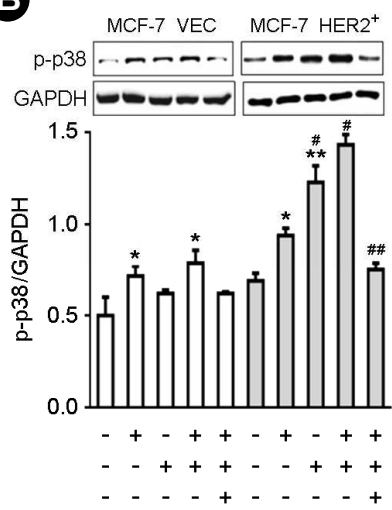

C

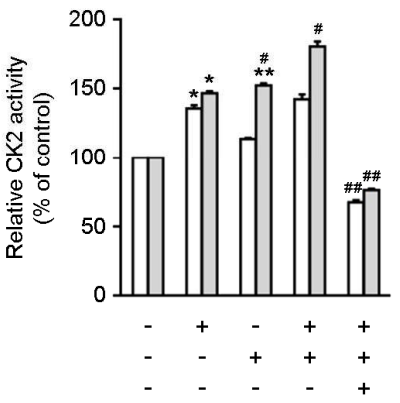

(D)

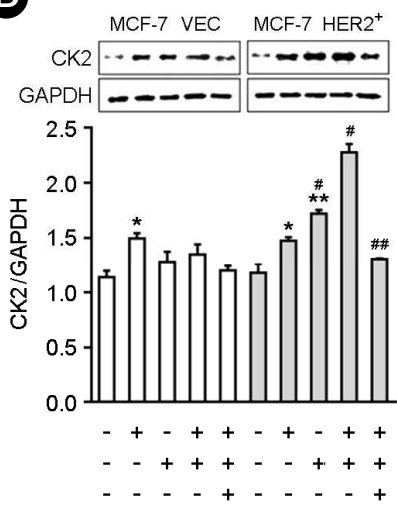

Fig. 3. EGF increases ROS production, CK2 activity and protein expression in MCF-7 HER2 ${ }^{+}$cells. MCF-7 vec or MCF-7 HER $2^{+}$ cells $\left(4 \times 10^{3} /\right.$ well for A; $1 \times 10^{6} /$ well for B and C) were pretreated with NAC $(30 \mu \mathrm{g} / \mathrm{mL})$ for 30 min followed by estrogen $(0.5 \mu \mathrm{M})$ or EGF (50 ng/mL) for the measurement of ROS (A), p38 phosphorylation (B), CK2 activity (C) and protein expression (D). Data represent the mean $\pm \mathrm{SE}$ of two to three independent experiments with three to five samples each. ${ }^{*} P<0.01$ versus control group. ${ }^{* * *} P<0.001$ versus control group. ${ }^{\#} P<0.01$ versus EGF-treated MCF-7 vec group. ${ }^{\# \#} P<0.001$ versus estrogen + EGF-treated group.
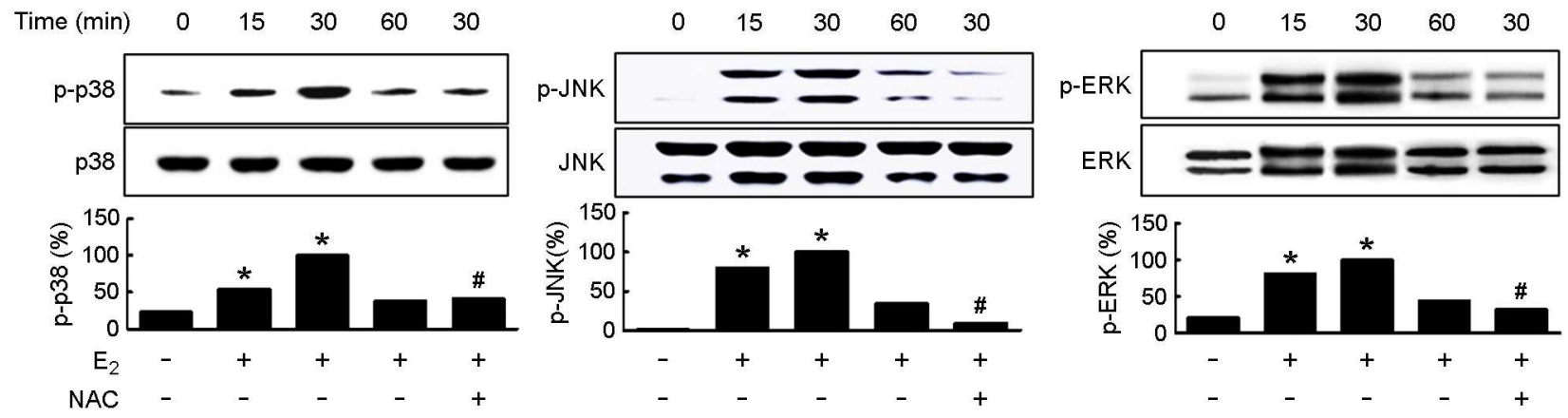

Fig. 4. Estrogen induces MAPK phosphorylation in MCF-7 cells. Cells $\left(1 \times 10^{6}\right)$ were treated with estrogen $(0.5 \mu \mathrm{M})$ for the time indicated to measure the phosphorylation of p38, JNK, and ERK. To see the effect of NAC, cells were pretreated with NAC $(30 \mu \mathrm{g} / \mathrm{mL})$ for $30 \mathrm{~min}$, and were cultured for another $30 \mathrm{~min}$ with estrogen. Data represent the mean $\pm \mathrm{SE}$ of three independent experiments with three samples each. ${ }^{*} P<0.005$ versus control group. ${ }^{\#} P<0.001$ versus estrogen-treated group.

and CK2 $\alpha$ activity and expression.

\section{ROS-dependent p38 mediates CK2 $\alpha$ activation}

We next investigated the roles of p38, JNK, and ERK MAPK in estrogen-induced CK2 $\alpha$ activation. Estrogen induced phosphorylation of the three MAPK in MCF-7 cells, all of which were blocked by NAC (Fig. 4). Pre-treatment of cells with the p38 inhibitor, SB202190, blocked estrogeninduced increases in CK2 $\alpha$ activity (Fig. 5A) and protein expression (Fig. 5B). JNK inhibitor or ERK inhibitor failed to inhibit estrogen-induced CK2 $\alpha$ expression (data not shown), suggesting that JNK and ERK do not involved importantly in this context. Further, SB202190 inhibited $\mathrm{H}_{2} \mathrm{O}_{2}$-induced CK2 $\alpha$ activation (Fig. 5C) and protein expression (Fig. 5D), suggesting that p38 mediated CK2 $\alpha$ activity and protein expression.

\section{DISCUSSION}

The mechanism of CK2 $\alpha$ overexpression in breast cancers is poorly understood. In this study, we showed that estrogen induced CK2 $\alpha$ activation and protein expression via ROS/ p38 signaling. It is well known that estrogen increases ROS production via several mechanisms including estrogen me- 
A

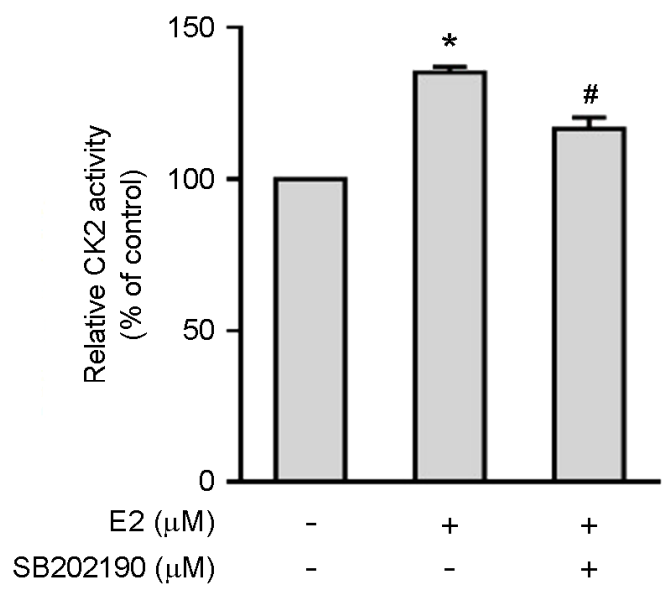

C

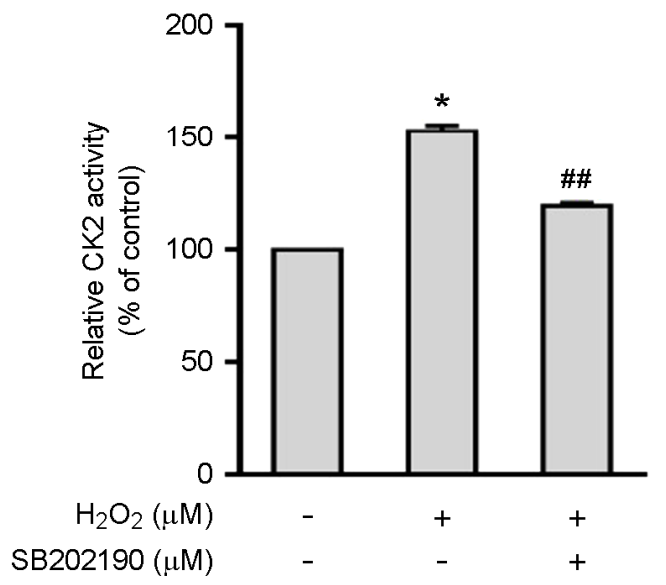

B
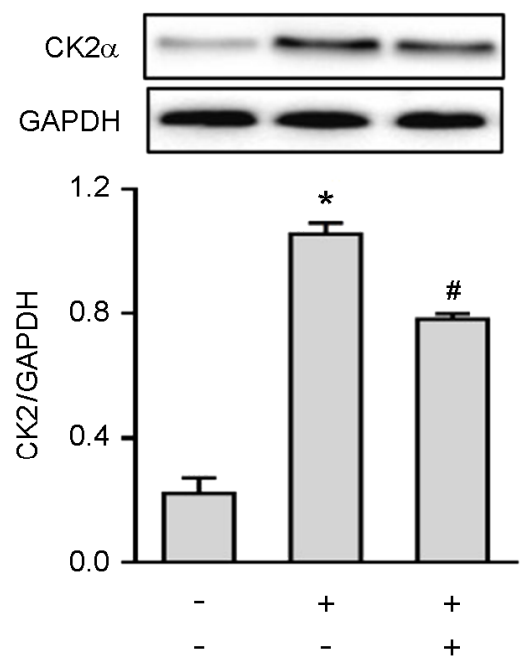

(D)
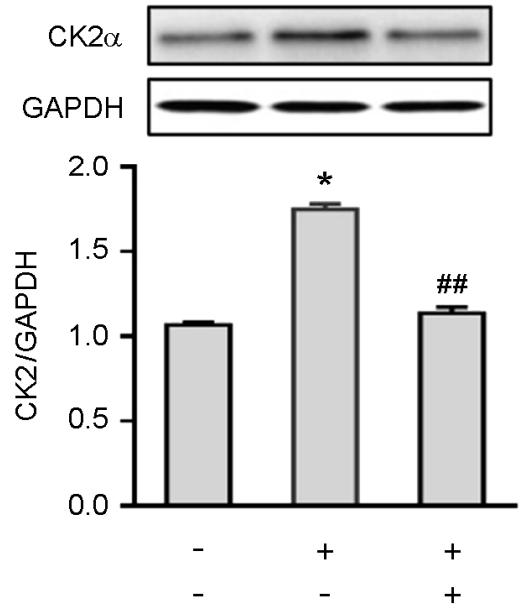

Fig. 5. The p38 mediates estrogen-induced CK2 activation in MCF-7 cells. Cells $\left(1 \times 10^{6}\right)$ were pretreated with SB202190 $(20 \mu \mathrm{M})$ for $30 \mathrm{~min}$ followed by estrogen $(0.5 \mu \mathrm{M}, \mathrm{A}$ and $\mathrm{B})$ or $\mathrm{H}_{2} \mathrm{O}_{2}(30 \mu \mathrm{M}, \mathrm{C}$ and $\mathrm{D})$ for the measurement of $\mathrm{CK} 2$ activity $(\mathrm{A}, \mathrm{C})$ and protein expression (B, D). Data represent the mean $\pm \mathrm{SE}$ of two to three independent experiments with three to five samples each. ${ }^{*} P<0.01$ versus control group. ${ }^{\#} P<0.01$ versus estrogen-treated group. ${ }^{\# \#} P<0.01$ versus $\mathrm{H}_{2} \mathrm{O}_{2}$-treated group.

tabolism and generation of genotoxic estrogen metabolites such as catechol estrogen and estrogen-semi-quinones (Roy et al., 2007; Okoh et al., 2011). We found that estrogen produced ROS in ER ${ }^{+} \mathrm{MCF}-7$ and T47D cells, but not in $\mathrm{ER}^{-}$ MDA-MB-231 cells. ROS can be generated intracellularly by a variety of enzymes (i.e., NADPH oxidase, xanthine oxidase, lipoxygenase) and through the mitochondrial respiratory chain (Sauer et al., 2001). Mitochondria however, are the largest source of ROS in epithelial cells. Studies have shown that mitochondria is the major source of intracellular ROS in response to estrogen (Felty et al., 2005).

The ROS generated by estrogen induced CK2 $\alpha$ activation and protein expression via $\mathrm{CK} 2 \alpha$ activation and protein expression, which were blocked by NAC. The ROS $\left(\mathrm{H}_{2} \mathrm{O}_{2}\right)$ also directly increased the CK2 $\alpha$ activity and protein expression.

The members of the epidermal growth factor receptor (EGFR)/ErbB family: EGFR (also known as ErbB1 and HER1), HER2 (also known as HER2/neu and ErbB2), ErbB3 (also known as HER3), and ErbB4 (also known as 
HER4) are the most notable cancer molecular targets identified to date (Mendelsohn and Baselga, 2003). Overexpression of HER2, which is a transmembrane receptor tyrosine kinase (Groenen et al., 1994; Lemke, 1996) is seen in 30\% of breast cancer patients and is associated with poor survival, increased metastasis, and resistance to chemotherapy (Slamon et al., 1987; Toikkanen et al., 1992). As a result, HER2 is the most well established therapeutic target in breast cancer. EGFR overexpression is observed in all subtypes of breast cancer, EGFR is more frequently overexpressed in triplenegative breast cancer (TNBC) and inflammatory breast cancer, which are especially aggressive (Rakha et al., 2007; Burness et al., 2010).

In addition to estrogen, we observed that EGF increased ROS levels and CK2 activation as well in MCF-7 HER 2 cells. Treatment of the cells with the combinations of estrogen and EGF led to enhanced ROS and CK2 $\alpha$ activation compared with stimulation with either estrogen or EGF alone. What is the mechanism of up-regulation of ROS/ CK2 $\alpha$ in MCF-7 HER 2 cells? NADPH oxidase was specifically involved in the generation of ROS by growth factors, such as transforming growth factor- $\beta 1$ (Ohba et al., 1994; Thannickal and Fanburg, 1995), insulin (Mahadev et al., 2001), PDGFand EGF (Sundaresan et al., 1995; Bae et al., 1997). Additionally, we previously reported that exogenous stimuli such as platelet activating factor, LPS, TNF- $\alpha$, and interleukin-1 triggering ROS generation were found to enhance CK2 $\alpha$ activity (Kim et al., 2014). Therefore, up-regulation of CK2 $\alpha$ in MCF-7 HER 2 cells is probably attributed to EGFdependent generation of higher levels of ROS, which may explain the aggressive features of HER2-positive breast carcinomas and their rapid proliferation compared with other types of breast cancer (Me'nard et al., 2003).

The p38 MAPK signaling pathway mediates the inflammatory response via proteins, such as proinflammatory cytokines, chemokines, degradative enzymes, growth factors, and adhesion molecules (Zhang et al., 2007). P38 is an oxidative stress-sensitive kinase. During the ROS-mediated p38 activation, a few protein kinases, such as apoptosis signal-regulated kinase 1, an upstream MAPK kinase kinases (Saitoh et al., 1998; Fujino et al., 2007), cGMP-dependent protein kinase (Li et al., 2006; Hofmann et al., 2006), protein kinase A
(Brennan et al., 2006), and protein kinase C (Giorgi et al., 2010) that are directly regulated by ROS, are known to phosphorylate and activate p38 MAPK. We have previously reported that p38 is involved in ROS-mediated CK2 $\alpha$ modulation (Kim et al., 2014). Consistent with these findings, we demonstrated that p38 phosphorylation occurred in response to estrogen, which was abrogated by pre-treatment with NAC, indicating that ROS generated by estrogen induced p38 phosphorylation. Indeed, the p38 inhibitor, SB202190, was shown to inhibit CK2 $\alpha$ activation and protein expression (Fig. 5), indicating that p38 kinase catalyzed ROS-mediated CK2 $\alpha$ activation and protein expression. Therefore, apparently ROS/p38 is a key common upstream pathway underlying the enhanced $\mathrm{CK} 2 \alpha$ activity, suggesting that the ROS/ p38 leading to CK2 $\alpha$ activation mediated estrogen signaling.

Classification of breast cancer has been historically based on both analysis of tumor morphology and histological detection of three marker proteins: the ER, the progesterone receptor (PR), and the HER2 or ErbB2. Tumors which express none of these three markers are collectively referred to as triple-negative breast cancer (TNBC; ER, $\mathrm{PR}^{-}, \mathrm{HER} 2^{-}$). More recent gene expression analyses showed that breast cancer is a more heterogeneous disease than previously assumed. The current classification includes five major transcriptional subtypes: basal-like, HER2-enriched, luminal A, luminal B, and normal breast-like (Perou et al., 2000; Sorlie et al., 2003). Recently, the aberrant expression of CK2 $\alpha$ and its subtypes in breast cancers has been reported (Giusiano et al., 2011). Therefore, it is of interest to investigate the linkage between oxidative stress and p38/CK2 $\alpha$ expression in various types of breast cancer in the future.

In summary, we demonstrated that ROS/p38 acts as a key inducer of CK2 $\alpha$ activation in response to estrogen or growth factor (EGF) stimulation, i.e., estrogen or EGF $\rightarrow$ $\operatorname{ROS} \uparrow \rightarrow \mathrm{p} 38 \mathrm{MAPK} \uparrow \rightarrow \mathrm{CK} 2 \alpha$ activation $\uparrow$. Therefore, this study adds an important element to our understanding of the mechanisms underlying $\mathrm{CK} 2 \alpha$ activation in breast cancers.

\section{ACKNOWLEDGEMENT}

This work was supported by the Mid-Career Researcher Program through the National Research Foundation of Korea 
(NRF) grant (No. 2015-1397, 2016-1093).

\section{CONFLICT OF INTEREST}

No conflicts of interest are involved in this manuscript.

\section{REFERENCES}

Allende JE, Allende CC. Protein kinases. 4. Protein kinase CK2: an enzyme with multiple substrates and a puzzling regulation. FASEB Journal. 1995. 9: 313-323.

Bae YS, Kang SW, Seo MS, Baines IC, Tekle E, Chock PB, Rhee SG. Epidermal growth factor (EGF)-induced generation of hydrogen peroxide. Role in EGF receptor-mediated tyrosine phosphorylation. Journal of Biological Chemistry. 1997. 272: 217-221.

Brennan JP, Bardswell SC, Burgoyne JR, Fuller W, Schröder E, Wait R, Begum S, Kentish JC, Eaton P. Oxidant-induced activation of type I protein kinase A is mediated by RI subunit interprotein disulfide bond formation. Journal of Biological Chemistry. 2006. 281: 21827-21836.

Burness ML, Grushko TA, Olopade OI. Epidermal growth factor receptor in triplenegative and basal-like breast cancer: promising clinical target or only a marker? Cancer Journal. 2010. 16: $23-32$.

Carew JS, Huang P. Mitochondrial defects in cancer. Molecular Cancer. 2002. 1: 15.

Chua MM, Ortega CE, Sheikh A, Lee M, Abdul-Rassoul H, Hartshorn KL, Dominguez I. CK2 in Cancer: Cellular and biochemical mechanisms and potential therapeutic target. Pharmaceuticals (Basel). 2017. 10: 30.

Clemons M, Goss P. Estrogen and the risk of breast cancer. New England Journal of Medicine. 2001. 344: 276-285.

Duncan JS, Litchfield DW. Too much of a good thing: the role of protein kinase CK2 in tumorigenesis and prospects for therapeutic inhibition of CK2. Biochimica et Biophysica Acta. 2008. 1784: 33-47.

Felty Q. Singh, KP, Roy D. Estrogen-induced G1/S transition of $\mathrm{G} 0$-arrested estrogen-dependent breast cancer cells is regulated by mitochondrial oxidant signaling. Oncogene. 2005. 24: 4883 $-4893$.

Felty Q, Xiong WC, Sun D, Sarkar S, Singh KP, Parkash J, Roy D. Estrogen induced mitochondrial reactive oxygen species as signal-transducing messengers, Biochemistry. 2005. 44: 6900 -6909 .
Ferlay J, Shin HR, Bray F, Forman D, Mathers C, Parkin DM. Estimates of worldwide burden of cancer in 2008: GLOBOCAN 2008. International Journal of Cancer. 2010. 127: 2893-2917.

Filhol O, Giacosa S, Wallez Y, Cochet C. Protein kinase CK2 in breast cancer: the $\mathrm{CK} 2 \beta$ regulatory subunit takes center stage in epithelial plasticity. Cellular and Molecular Life Sciences. 2015. 72: 3305-3322.

Fujino G, Noguchi T, Matsuzawa A, Yamauchi S, Saitoh M, Takeda K, Ichijo H. Thioredoxin and TRAF Family Proteins Regulate Reactive Oxygen Species-Dependent Activation of ASK1 through Reciprocal Modulation of the N Terminal Homophilic Interaction of ASK1. Molecular and Cellular Biology. 2007. 27: 8152-8163.

Giorgi C, Agnoletto C, Baldini C, Bononi A, Bonora M, Marchi S, Missiroli S, Patergnani S, Poletti F, Rimessi A, Zavan B, Pinton P. Redox control of protein kinase C: Cell-and disease-specific aspects. Antioxidants \& Redox Signaling. 2010. 13: 1051-1085.

Giusiano S, Cochet C, Filhol O, Duchemin-Pelletier E, Secq V, Bonnier P, Carcopino X, Boubli L, Birnbaum D, Garcia S, Iovanna J, Charpin C. Protein kinase CK2 $\alpha$ subunit overexpression correlates with metastatic risk in breast carcinomas: quantitative immunohistochemistry in tissue microarrays. European Journal of Cancer. 2011. 47: 792-801.

Groenen LC, Nice E, Burgess AW. Structure-function relationships for the EGF/TGF-alpha family of mitogens. Growth Factors. 1994. 11: 235-257.

Hofmann F, Feil R, Kleppisch T, Schlossmann J. Function of cGMP Dependent Protein Kinases as Revealed by Gene Deletion. Physiological Review. 2006. 86: 1-23.

Kim KJ, Cho KD, Jang KY, Kim HA, Kim HK, Lee HK, Im SY. Platelet-activating factor enhances tumor metastasis via the reactive oxygen species-dependent protein kinase casein kinase 2-mediated nuclear factor- $\kappa$ B activation. Immunology. 2014. 143: 21-32.

Lemke G. Neuregulins in development. Molecular and Cellular Neuroscience. 1996. 7: 247-262.

Li Z, Zhang G, Feil R, Han J, Du X. Sequential activation of p38 and ERK pathways by cGMP-dependent protein kinase leading to activation of the platelet integrin $\alpha \operatorname{IIb} \beta 3$. Blood. 2006. 107: 965-972.

Litchfield DW. Protein kinase CK2: structure, regulation and role in cellular decisions of life and death. Biochemical Journal. 2003. 369: 1-15.

Mahadev K, Zilbering A, Zhu L, Goldstein BJ. Insulin-stimulated hydrogen peroxide reversibly inhibits protein-tyrosine phos- 
phatase $1 \mathrm{~b}$ in vivo and enhances the early insulin action cascade. Journal of Biological Chemistry. 2001. 276: 21938-21942.

Me'nard S, Pupa SM, Campiglio M, Tagliabue E. Biologic and therapeutic role of HER2 in cancer. Oncogene. 2003. 22: 6570 -6578 .

Mendelsohn J, Baselga J. Status of epidermal growth factor receptor antagonists in the biology and treatment of cancer. Journal of Clinical Oncology. 2003. 21: 2787-2799.

Ohba M, Shibanuma M, Kuroki T, Nose K. Production of hydrogen peroxide by transforming growth factor-beta 1 and its involvement in induction of egr-1 in mouse osteoblastic cells. Journal of Cell Biology. 1994. 126: 1079-1088.

Okoh V, Deoraj A, Roy D. Estrogen-induced reactive oxygen species-mediated signalings contribute to breast cancer. Biochim Biophys Acta. 2011. 1815: 115-133.

Parkash J, Felty Q, Roy D. Estrogen exerts a spatial and temporal influence on reactive oxygen species generation that precedes calcium uptake in high-capacity mitochondria: implications for rapid nongenomic signaling of cell growth. Biochemistry. 2006. 45: 2872-2881.

Perou CM, Sørlie T, Eisen MB, van de Rijn M, Jefrey SS, Rees CA, Pollack JR, Ross DT, Johnsen H, Akslen LA, Fluge O, Pergamenschikov A, Williams C, Zhu SX, Lønning PE, Børresen-Dale AL, Brown PO, Botstein D. Molecular portraits of human breast tumours. Nature. 2000. 406: 747-752.

Rakha EA, El-Sayed ME, Green AR, Lee AH, Robertson JF, Ellis IO. Prognostic markers in triple-negative breast cancer. Cancer. 2007. 109: 25-32.

Roy D, Cai Q, Felty Q, Narayan S. Estrogen-induced generation of reactive oxygen and nitrogen species, gene damage, and estrogen-dependent cancers. Journal of Toxicology and Environmental Health Part B Critical Reviews. 2007. 10: 235-257.

Saitoh M, Nishitoh H, Fujii M, Takeda K, Tobiume K, Sawada Y, Kawabata M, Miyazono K, Ichijo H. Mammalian thioredoxin is a direct inhibitor of apoptosis signal-regulating kinase (ASK) 1. EMBO Journal. 1998. 17: 2596-2606.

Sauer H, Wartenberg M, Hescheler J. Reactive oxygen species as intracellular messengers during cell growth and differentiation. Cellular Physiology and Biochemistry. 2001. 11: 173-186.

Seo HS, Choi HS, Kim SR, Choi YK, Woo SM, Shin I, Woo JK,
Park SY, Shin YC, Ko SG. Apigenin induces apoptosis via extrinsic pathway, inducing p53 and inhibiting STAT3 and NFkB signaling in HER2-overexpressing breast cancer cells. Molecular Cellular Biochemistry. 2012. 366: 319-334.

Singh NN, Ramji DP. Protein kinase CK2, an important regulator of the inflammatory response? Journal of Molecular Medicine (Berl). 2008. 86: 887-897.

Slamon DJ, Clark GM, Wong SG, Levin WJ, Ullrich A, McGuire WL. Human breast cancer: correlation of relapse and survival with amplification of the HER-2/neu oncogene. Science. 1987. 235: $177-182$.

Sorlie T, Tibshirani R, Parker J, Hastie T, Marron JS, Nobel A, Deng S, Johnsen H, Pesich R, Geisler S, Demeter J, Perou CM, Lnning PE, Brown PO, Brresen-Dale AL, Botstein D. Repeated observation of breast tumor subtypes in independent gene expression data sets. Proceedings of the National Academy of Sciences of the USA. 2003. 100: 8418-8423.

Sundaresan M, Yu ZX, Ferrans VJ, Irani K, Finkel T. Requirement for generation of $\mathrm{H}_{2} \mathrm{O}_{2}$ for platelet-derived growth factor signal transduction. Science. 1995. 270: 296-299.

Thannickal VJ, Fanburg BL. Activation of an $\mathrm{H}_{2} \mathrm{O}_{2}$-generating NADH oxidase in human lung fibroblasts by transforming growth factor beta 1. Journal of Biological Chemistry. 1995. 270: 30334-30338.

Toikkanen S, Helin H, Isola J, Joensuu H. Prognostic significance of HER-2 oncoprotein expression in breast cancer: a 30-tear follow-up. Journal of Clinical Oncology. 1992. 10: 1044-1048.

Yager JD, Liehr JG. Molecular mechanisms of estrogen carcinogenesis. Annual Review of Pharmacology and Toxicology. 1996. 36: 203-232.

Zhang J, Shen B, Lin A. Novel strategies for inhibition of the p38 MAPK pathway. Trends Pharmacological Sciences. 2007. 28: 286-295.

https://doi.org/10.15616/BSL.2019.25.1.23

Cite this article as: Jeong SY, Im SY. Estrogen Induces CK2 $\alpha$ Activation via Generation of Reactive Oxygen Species. Biomedical Science Letters. 2019. 25: 23-31 